\title{
Use of morphological and anatomical characters to delimit varieties of Paliurus spina-christi Mill. (Rhamnaceae)
}

Uso de caracteres mofologicos y anatomicos para delimiter variadades de Paliurus spina-christi Mill. (Rbamnaceae)

Author:

Saleem E. Shahbaz ${ }^{1}$

Nazar M. Shareef ${ }^{2}$

\section{SCIENTIFIC RESEARCH}

How to cite this paper:

Shahbaz S E., and Shareef N M., Use of Morphological and Anatomical Characters to delimit Varieties of Paliurus spina-christi Mill. (Rhamnaceae). Innovaciencia. 2018; 6(2): 1-14. http://dx.doi.org/10.15649/2346075X.471

Reception date:

Received: 24 April 2018

Accepted: 28 August 2018

Published: 28 December 2018

Keywords:

Paliurus spina-chriti L. var. spina-chriti, Paliurus spina-christi var. macrocarpa Beck., Isobilateral mesophyll, leaf anatomy, Petiole anatomy, Cuticular structure.

\section{ABSTRACT}

Introduction: Paliurus spina-christi Mill is a species with two varieties namely Paliurus spina-christi L. var. spina-christi and Paliurus spina-christi var. macrocarpa Beck native to mountains of Kurdistan, rarely growing in the upper plains of northern Iraq. Materials and Methods: A total of 15 plants from different parts of Kurdistan region were sampled. 30measurements for each characters of Leaf, Inflorescence, Flowers, Fruit, seeds, and leaf anatomical characters were measured for comparison between the two varieties. Results and Discussion: Fruit diameter of var. macrocarpa is significantly larger than fruit diameter of var. spina-christi. Most mean flower parts especially the ovary, in addition to seed size is larger in var. macrocarpa. Upper epidermal layer is always thicker than the lower epidermal layer for the same blade. The isobilateral mesophyll includes 2 layers of long palisade cells adaxially and 2-3 layers of short cells abaxially. Many vascular bundles are seen equally spaced in the mesophyll tissue.With the exception of the presence of simple hairs on the petiole adaxial side of the var. spina-cristi and the absence of these hairs from the same site of var. macrocarpa, all other anatomical features are considered to be of no taxonomic application. Stomatal density of the adaxial leaf side is up to 19 stomata per $\mathrm{mm}^{2}$ in var. spina-christi while it is up to 38 stomata per $\mathrm{mm}^{2}$ in var. macrocarpa. Conclusions: Both fruit diameter and the stomatal density of the adaxial leaf side constitute diagnostic characters for separating between the two varieties of Paliurus spina-christi Mill.

\footnotetext{
1 Professor of Plant Taxonomy, College of Agriculture, University of Duhok, email: saleem.shahbaz@uod.ac.

2 MSc in Plant Taxonomy, Ministry of Agriculture, Duhok Sector.
} 


\section{INTRODUCCTION}

Paliurus Mill., according to Townsend and Guest (1) is a genus of 6 species; only Paliurus spina-chriti Mill. is present natively to Kurdistan region. The species is so widely distributed in different physiographical region of northern Iraq as to recognize two varieties namely Paliurus spina-chriti var. spina-chriti with the fruits, as indicated by Townsend and Guest ${ }^{(1)}$ less than $2.5 \mathrm{~mm}$ in diameter and P. spina-chriti var. macrocarpa Beck. With the fruits diameter between 2.5-3.2 $\mathrm{cm}$. The extant genus Paliurus from the Miocene of East China is divided by Xiangchuan et al., ${ }^{(2)}$ into $P$. ramosissimus and $P$. spina-christi groups based on analyses of the present and previous fossil fruit records. According to the researchers, diversification of $\mathrm{Pa}$ liurus had begun in northern transpacific regions by the Late Eocene.

The Germplasm Resources Information Network (GRIN) recognizes 9 species. In their revision of Rhamnaceae, ${ }^{(3)}$ indicated that the genus of Paliurus in China consist of: P. hirsutus, P. ramosissimus (Lour.) Poir., P. spina-christi Mill., P. orientalis (Franch.) Hemsl., and P. hemsleyanus Reh. ex Schir. and Ola. For Basinger and Dilcher ${ }^{(4)}$, the Rhamnaceae appears to be an old lineage because a rhamnaceous flower has been found dating back to 94-96 million years ago. For Manchester ${ }^{(5)}$, the fossil records of Paliurus, based mostly on leaves and fruit characters, are very soundly identified in tertiary flora, and are significant in understanding the biogeographic affinities of North American tertiary flora.

The Paliurus flowers, like other Rhamnaceae flowers, are antipetalous (obhaplostemony) and possess tendency towards xeromorphism. Obhaplostemony is considered a relatively rare character in angiosperms, and this has resulted in associating Rhamnaceae with other families such as Vitaceae and Cornaceae which exhibit the same arrangement. The xeromorphic of adaptations to aridity exhibited by some members of the Rhamnaceae consist of reduction or absence of leaves, crowding of leaves, shortening of branch axes, presence of thorns or spines, and a low, shrubby habit.

Literature on the leaf anatomy of our native species P. spina-christi is not available on the level of Iraq, and is rare even universally. Wood anatomy has been more investigated ${ }^{(6)}$. On the other hand, Literature is too much on the leaf anatomy of the closely related species of the genus Ziæiphus Mill. Investigation of Z. nummularia (Burm.F.) and Z. spina-christi L. leaves shows anatomical characters of xerophyte plants such as high frequently of papilla on both leaf surfaces, epidermis with thick cuticle and stomata sunken in crypts ${ }^{(7)}$. In contrary, Z. jujube Mill has superficial stomata and simple papilla which is rarely observed on the abaxial surface of the leaf midrib, moreover, epidermis consists of one layer of large cells. Stomata are anisocytic. Leaf isobilateral mesophyll includes 3-4 layers of long palisade cells adaxially and 2-3 layers of short cells on abaxial surface. Each vascular bundle is collateral and surrounded by parenchymatous bundle sheath ${ }^{(8)}$.

Paliurus spina-chriti is commonly distributed in mountains of Kurdistan, very rarely in the upper plains of northern Iraq. Often grows in the lower forest zone, in degraded woodland, mostly near streams and other water sources, up to $1500 \mathrm{~m}$ altitude ${ }^{(1)}$. Plants are widely used for hedging. In traditional medicine, the plant is usually effective as a hyposcholesterolemic, antihypertensive, astringent, and tonic, diuretic.

The aim of this study is to provide a detailed description and to present more accurate and distinct diagnostic characters for distinguishing the two infra specific taxa of $C$. tournefortii var. spina-christi and $C$. tournefortii var. macrocarpa using morphological and anatomical traits. 


\section{MATERIALS AND METHOD}

Field expeditions were started in 2014, continued during 2015 with the aim of collecting Paliurus spina-christi throughout Kurdistan region. Selection was preliminary based on previous literature ${ }^{(1,9)}$, herbarium specimens deposited in different Iraqi herbaria, indigenous information and the conspicuous presence of the target species. 10 field trips were conducted each more lasted from 1-5 days. A total of 15 plants from different parts of Kurdistan region were sampled. An equal number of herbarium specimens were prepared and deposited in the herbarium of the College of Agriculture/ University of Duhok (DPUH) (table 1). Thirty measurements were taken for each of the following characters:

\section{Leaf:}

Blade length, Blade width, Blade length/Blade width,
Petiole length, Shape of blade apex, Shape of blade base. Petiole length, diameter, color, shape, leaf indumentum.

\section{Inflorescence:}

Inflorescence type, length, width, length/width ratio, color, number of flowers/inflorescence, peduncle length, peduncle width (at the mid-point).

\section{Flowers:}

Calyx, corolla, stamens (number, shape, color, dimensions, indumentum); pistile: ovary, style, stigma (shape, color, dimension, number, indumentums), pedicel length, receptacle shape and dimension.

\section{Fruit and seeds:}

Fruit length, width, length/ width ratio, thickness. Seed length, width, thickness.

Table 1-a. Specimens from Iraq Herbaria Used in the Study, Abbreviation According to Holmgren and Keuken ${ }^{(10)}$.

\begin{tabular}{|c|c|c|c|c|c|c|}
\hline Taxon & Herbarium & $\begin{array}{l}\text { Collected } \\
\text { position }\end{array}$ & Collector & $\begin{array}{l}\text { Altitude } \\
\text { (m) }\end{array}$ & $\begin{array}{c}\text { Date of } \\
\text { Collection }\end{array}$ & $\begin{array}{l}\text { Specimen } \\
\text { Number }\end{array}$ \\
\hline \multirow{8}{*}{$\begin{array}{l}\text { Paliurus spina- } \\
\text { christi } \\
\text { var.spina- } \\
\text { christi }\end{array}$} & BAG & $\begin{array}{l}\text { Khurda Look } \\
\text { village (Dukan) }\end{array}$ & A. Rawi & 740 & $14 / 6 / 1957$ & 21788 \\
\hline & BAG & $\begin{array}{l}\text { Bikhair } \\
\text { mountain }\end{array}$ & A. Rawi & 800 & $27 / 5 / 1957$ & 22966 \\
\hline & BAG & $\begin{array}{c}\text { Armotah village } \\
\text { (Koi Sangak) }\end{array}$ & $\begin{array}{l}\text { S. Omer \& } \\
\text { F. Karim }\end{array}$ & 775 & 17/4/1970 & 37254 \\
\hline & BAG & Shaqlawa & F. Karim & & $13 / 5 / 1970$ & 37516 \\
\hline & BAG & Aqra & A. Rawi & 1000 & $31 / 5 / 1948$ & 11373 \\
\hline & BAG & Sarchinar & J. B. Gillett & 800 & $16 / 4 / 1947$ & 7687 \\
\hline & BAG & Tagaran Stream & & 866 & $9 / 9 / 2014$ & $14-2559$ \\
\hline & SUAH & Hawar & Saman A. & 922 & $21 / 5 / 2012$ & $12-555$ \\
\hline \multirow{5}{*}{$\begin{array}{l}\text { Paliurus spina- } \\
\text { christi var. } \\
\text { morocarpa }\end{array}$} & $\mathrm{BAG}$ & $\begin{array}{c}\text { Between } \\
\text { Shaqlawa \& } \\
\text { Harir }\end{array}$ & S. Omer & \multirow{5}{*}{700} & $11 / 6 / 1970$ & 37623 \\
\hline & $\mathrm{BAG}$ & $\begin{array}{l}\text { Ain Terma } \\
\text { (Shaqlawa) }\end{array}$ & Sahira & & $17 / 7 / 1970$ & 37573 \\
\hline & BAG & Jindian & Evan Guest & & 24/8/1930 & 13003 \\
\hline & BAG & $\begin{array}{c}\text { Hauraman } \\
\text { mountain }\end{array}$ & $\begin{array}{c}\text { Chak, Rawi } \\
\text { and Nuri }\end{array}$ & & $26 / 6 / 1961$ & 19716 \\
\hline & BAG & Safin Dgh & F. Karim & & 11/7/1972 & 39392 \\
\hline
\end{tabular}

National Herbarium of Iraq - Baghdad (BAG).

Sulaimaniy University Agriculture Herbarium (SUAH). 
Table 1-b. Herbarium specimens deposited in Duhok University Herbarium (DPUH).

\begin{tabular}{ccccccc}
\hline Taxon & $\begin{array}{c}\text { Collected } \\
\text { position }\end{array}$ & $\begin{array}{c}\text { Altitude } \\
(\mathbf{m})\end{array}$ & Longitude & Latitude & $\begin{array}{c}\text { Date of } \\
\text { Collection }\end{array}$ & $\begin{array}{c}\text { Specimen } \\
\text { Number }\end{array}$ \\
$\begin{array}{c}\text { Zawita } \\
\begin{array}{c}\text { Paliurus spina-christi } \\
\text { var.spina-christi }\end{array}\end{array}$ & $\begin{array}{c}\text { Gali Ali Beg } \\
\text { Zarda Bi } \\
\text { village }\end{array}$ & 570 & $43.136941 \mathrm{E}$ & $36.889674 \mathrm{~N}$ & $14 / 5 / 2014$ & 3592 \\
& 856 & $44.451229 \mathrm{E}$ & $36.626912 \mathrm{~N}$ & $3 / 5 / 2015$ & 3594 \\
\hline $\begin{array}{c}\text { Paliurus spina-christi } \\
\text { var. macrocarpa }\end{array}$ & $\begin{array}{c}\text { Zawita } \\
\text { Bana Nok } \\
\text { (Shaqlawa) }\end{array}$ & 955 & $43.136492 \mathrm{E}$ & $36.889566 \mathrm{~N}$ & $23 / 5 / 2015$ & 3599 \\
\hline
\end{tabular}

\section{Leaf anatomy}

Mature leaves were collected from naturally growing plants of Paliurus spina-christii. Five leaves from each 15 trees were obtained. Samples for anatomical investigation were prepared according to Fathoulaah (11) and Saeed ${ }^{(12)}$ :

1. Killing and Fixation using FAA solution.

2. Washing and Dehydration by ascending concentration of ethanol.

3. Clearing and Infiltration by placing samples in a mixture of absolute alcohol and xylene and then in a mixture of melted paraffin and xylene.

4. Embedding and Mounting.

5. Removing of wax and staining

6. Staining Procedure.

\section{Cuticular Structure}

Mature leaves from trees or shrubs were selected for light microscope measurements. Samples were dehydrated using ethyl alcohol $90 \%$, then stored in $70 \%$ ethanol until to uses, and subsequently leaves of each taxon were sampled randomly from ethanol, washed in distilled water, dried, then immersed in glacial acetic acid and hydrogen peroxide (1:1 volumes), left in oven at $60^{\circ} \mathrm{C}$ for $20-40$ hours, depending on the species. Adaxial and abaxial peelings from the macerated leaves were stained with safranin-glycerin jelly, mounted on microscopic slides, covered by slides. The following measurements were recorded, average of 25 observations for each:

1. Abaxial and adaxial epidermal cell dimensions.
2. Epidermal cell density $=$ number of epidermal cells / mm2.

3. Stomatal dimensions.

4. Stomatal density $=$ number of stomata / $\mathrm{mm} 2$.

5. Stomatal index $\%=$ \{stomata density / (stomata density + epidermal cell density $\} * 100$.

6. Summary statistics (mean, range, and standard deviation) were calculated for each character.

\section{RESULTS AND DISCUSSION}

Paliurus spina-christi Mill., Gard. Divt. Ed. 8 (176); Nab. in Publ. Fac. Sci. Univ. Masaryk. 35: 63 (1923; Fl. Pal. Ed. 2, 1: 288(1932); Guest in Dep. Agr. Iraq Bull. 27: 70 1933); Bornm. In Beih. Bot. Centralbl. 57B: 249(137); Blackklock in Kew Bull. 3: 410(1948); Grubov in Fl. U. R. S.S. 14: 636 (1949); Zoh. in Dep. Agr. Iraq Bull. 31: 103(1950); Rawi in Dep. Agr. Iraq Tech. Bull. 4: 42 (1964); Fl. Turkey 2:523 (1967); Nouv. Fl. Syr. 2: 554 (1970).

Rhamnus paliurus L. Sp. Pl. ed. 1: 194 (1753).

Paliurus australis Gaertn., Fruct. 1: 203, t. 43, f. 5 (1758).

Paliurus aculeatus Lam., Tabl. Encycl. III. 2: 347, no. 611, t 210, f. 2 (1793); Fl. Orient. 2: 12 (1872).

Plants are shrubs or small trees. Branches zigzagged. Leaves are alternate, somewhat distichous, leathery, ovate, and 3-nerved from the base, entire, weakly serrulate or crenate margin, petiolate. Stipules are spinous, dimorphic. Flowers are hermaphrodite, in axillary cymes. Calyx 4-5(6-), with a poculiform tube and deltoid lobes, deciduous. Petals 4-5, inserted with the stamens on the disk. Ovary half immersed in the disk, 3 locular; styles 2-3. Fruits dray woody 
drupe centered in a circular wing, up to $12.08-36.17$ $\mathrm{mm}$.

\section{Paliurus spina-christi L. var. spina-christi}

Deciduous shrubs or small trees 2.5-4 m height, diameter at ground level $1.75-6.20 \mathrm{~cm}$, width 1-2.65 m. Lower bark smooth, dark brown sometime gray. Twigs are slender, zigzagged or flexuose, reddishbrown, smooth, spreading. Crown is open. Buds are small 1.10-2.51 mm length, 1.04-2.31 $\mathrm{mm}$ width, globular, brown, puberulent, densely wooly, bud scale shape ovate, outer surface hairy, inner side hairy or glabrous. Leaves are $0.801-7.20 \mathrm{~cm}$ long, and $0.501-4.50 \mathrm{~cm}$ wide, texture sub-coriaceous. Leaf shape is ovate to obliquely ovate, ad axially glossy green, abaxially dark green. Blade apex is obtuse, acute or acuminate; base oblique-rounded' margins entire, weakly serrulate or crenate; blade length/ blade width ratio $0.577-4.28$. Venation is 3 -nerved from the base. Leaf blade is $0.650-6.85 \mathrm{~cm}$ long, $0.501-4.50 \mathrm{~cm}$ wide. Petiole length is $0.150-1.80 \mathrm{~cm}$, rounded. Leaf length / Petiole length ratio is 3.12 - 19.20. Spine is straight, $0.639-1.569 \mathrm{~cm}$ long, recurve, $0.316-0.670 \mathrm{~cm}$ wide, dark brown, 2 on the outside of each knot, dimorphic, one straight and the other recurve and hooked. Inflorescences are yellowish cymes, born laterally, 0.801-2.21 cm long, and $1.20-2.31 \mathrm{~cm}$ wide. Flowers are actinomorphic, bisexual, small yellowish. Peduncle is $0.114-0.314 \mathrm{~cm}$ length and 0.057-0.085 cm diameter. Pedicel with $0.228-0.957 \mathrm{~cm}$ length, $0.028-0.057 \mathrm{~cm}$ width. Ovary with $0.065-0.146 \mathrm{~cm}$ length, $0.051-0.123 \mathrm{~cm}$ width, greenish-yellow, half-immersed in the disk, 3- locular. Style is $0.061-0.115 \mathrm{~cm}$ long, $0.015-0.025 \mathrm{~cm}$ wide, greenish-yellow, 2-3 lingual elongate with structure bubbly form. Stigma with $0.015-0.038 \mathrm{~cm}$ diameter, greenish-yellow, globular. Petal is 4-5, 0.095-0.193 cm long, 0.061-0.115 cm wide, yellow, ovate-spathulate more delicate, inserted with the stamens on the disk. Sepal is 4-5(-6), 0.153-0.264 cm long, and $0.143-0.261 \mathrm{~cm}$ wide, greenish-yellow, broadly deltoid-ovate, glabrous, firm. Filament is $0.085-0.153 \mathrm{~cm}$ long, and $0.015-0.023 \mathrm{~cm}$ wide, and greenish-yellow, oblate. Another is $0.045-0.053 \mathrm{~cm}$ long and 0.030 $0.045 \mathrm{~cm}$ wide, yellow, oblate. Bract is $0.115-0.385$ $\mathrm{cm}$ long and 0.021-0.096 cm wide, greenish, deltoid, hairy tapering to a point, margin serrate. Number of stamens is 4-6 free. Fruits are dry, indehiscent, depressed subglobose drupe with broad circular wing, light brown, glabrous, $12.08-24.32 \mathrm{~mm}$ diameter.
Peduncle with 2.21-8.06 mm length and 0.481-1.05 $\mathrm{mm}$ diameter. Pedicel with 12.09-19.16 mm length and $0.414-0.585 \mathrm{~mm}$ width. Stone (endocarp) with 6.56-8.85 $\mathrm{mm}$ length and 5.74-7.98 $\mathrm{mm}$ width, and brown, globular, smooth. Seed with 3.81-5.48 mm length and 3.34-4.83 mm width, 1.80-2.23 mm thickness, and flattened, dark brown, smooth. (Figure 1).

Paliurus spina-christi var. macrocarpa Beck. in Fedde Rep. 17:451(192).

Deciduous shrubs or small trees 2.5-3.7 m height, diameter at ground level 1.90-6.52 cm, width 1-2.5 m. Lower bark smooth, dark brown sometime gray. Twigs are slender, zigzagged or flexuose, reddishbrown, smooth, spreading. Crown is open. Buds are small 1.51-3.59 mm long and 1.38-3.51 mm wide, globular, brown, puberulent, and densely wooly, bud scale shape ovate, outer surface hairy, inner side hairy or glabrous, and sharpened. Leaves with 3.01 $-7.23 \mathrm{~cm}$ length, and 1.20-4.40 cm width, texture sub-coriaceous. Leaf shape ovate to obliquely ovate, adaxial leaf color glossy green, abaxial leaf color dark green, leaf blade apex obtuse, acute or acuminate, leaf blade base oblique-rounded, leaf blade entire, weakly serrulate or crenate; blade length/blade width ratio is $0.577-4.28$. Venation is 3 -nerved from the base. Leaf blade is $2.40-6.50 \mathrm{~cm}$ long and $1.20-4.40 \mathrm{~cm}$ wide. Petiole length is 0.501 $1.82 \mathrm{~cm}$, rounded. Leaf length / Petiole length ratio is $3.12-19.20$. Spines are 2 on the outside of each knot, dimorphic, one is straight, $0.710-2.06 \mathrm{~cm}$ long, and the other is recurve and hooked, 0.310-0.804 $\mathrm{cm}$ long. Inflorescences are yellowish cymes, born laterally, $1.12-2.42 \mathrm{~cm}$ long and $1.31-2.63 \mathrm{~cm}$ wide. Flowers are actinomorphic, bisexual, small yellowish. Peduncle is $0.214-0.471 \mathrm{~cm}$ length and 0.071-0.131 $\mathrm{cm}$ diameter. Pedicel is with $0.285-1.18 \mathrm{~cm}$ length and $0.043-0.071 \mathrm{~cm}$ width. Ovary is $0.116-0.177 \mathrm{~cm}$ long and 0.101-0.176 cm width, greenish-yellow, half-immersed in the disk, 3- locular. Style is 0.077$0.123 \mathrm{~cm}$ long and $0.030-0.046 \mathrm{~cm}$ wide, greenishyellow, 2-3 lingual elongate with structure bubbly form. Stigma is $0.034-0.048 \mathrm{~cm}$ diameter, greenishyellow, globular. Petal is 4-5, 0.192-0.246 cm long and $0.107-0.138 \mathrm{~cm}$ wide, yellow, ovate-spathulate more delicate, inserted with the stamens on the disk. Sepals are 4-5(-6) in number, 0.207-0.276 cm long and $0.207-0.272 \mathrm{~cm}$ wide, greenish-yellow, broadly deltoid-ovate, glabrous, firm. Filament is 0.131-0.192 $\mathrm{cm}$ long and $0.015-0.038 \mathrm{~cm}$ wide, greenish-yellow, oblate. Anther is 0.053-0.069 cm long and 0.038$0.057 \mathrm{~cm}$ wide, yellow, oblate. Bract is 0.181-0.231 
$\mathrm{cm}$ long and 0.038-0.092 $\mathrm{cm}$ wide, greenish, deltoid, hairy, tapering to a point, margin serrate. Stamens are free, 4-6 in number. Fruits are dry, indehiscent, depressed subglobose drupe with broad circular wing, light brown, glabrous, with 25.29-36.17 mm diameter. Peduncle is $1.13-7.12 \mathrm{~mm}$ long and 0.562$1.13 \mathrm{~mm}$ diameter. Pedicel is $12.06-18.11 \mathrm{~mm}$ long and $0.571-0.785 \mathrm{~mm}$ wide. Stone (endocarp) is $8.32-$ $10.48 \mathrm{~mm}$ long and $7.62-9.31 \mathrm{~mm}$ wide, brown, globular, smooth. Seed is 5.01-5.37 mm long, 3.95$4.60 \mathrm{~mm}$ wide, and $2.07-2.25 \mathrm{~mm}$ thick, flattened, dark brown, smooth. (Figure 2).

Key to the varieties based on fruits and seeds and leaves:
P. spina-christi var. macrocarpa: Fruits $2.52-3.61 \mathrm{~cm}$ in diameter, seed mean size up to $5.2 \times 4.16 \times 2.15 \mathrm{~mm}$. P. spina-christi var. spina-christi: Fruits $1.20-2.43 \mathrm{~cm}$ in diameter, seed mean size up to $4.57 \times 3.97 \times 2.02$ $\mathrm{mm} \times 6.85 \mathrm{~cm}$.

\section{Key to the varieties based on flower parts:}

P. spina-christi var. macrocarpa: Ovaries relatively large up to $0.76 \times 0.77 \mathrm{~cm}$ in size, styles up to $0.123 \mathrm{~cm}$ long, and filaments up to $0.192 \mathrm{~cm}$ long.

P. spina-christi var. spina-christi: Ovaries relatively small up to $0.123 \times 0.146 \mathrm{~cm}$ in size, styles up to $0.115 \mathrm{~cm}$ long, and filaments up to $0.153 \mathrm{~cm}$ long.

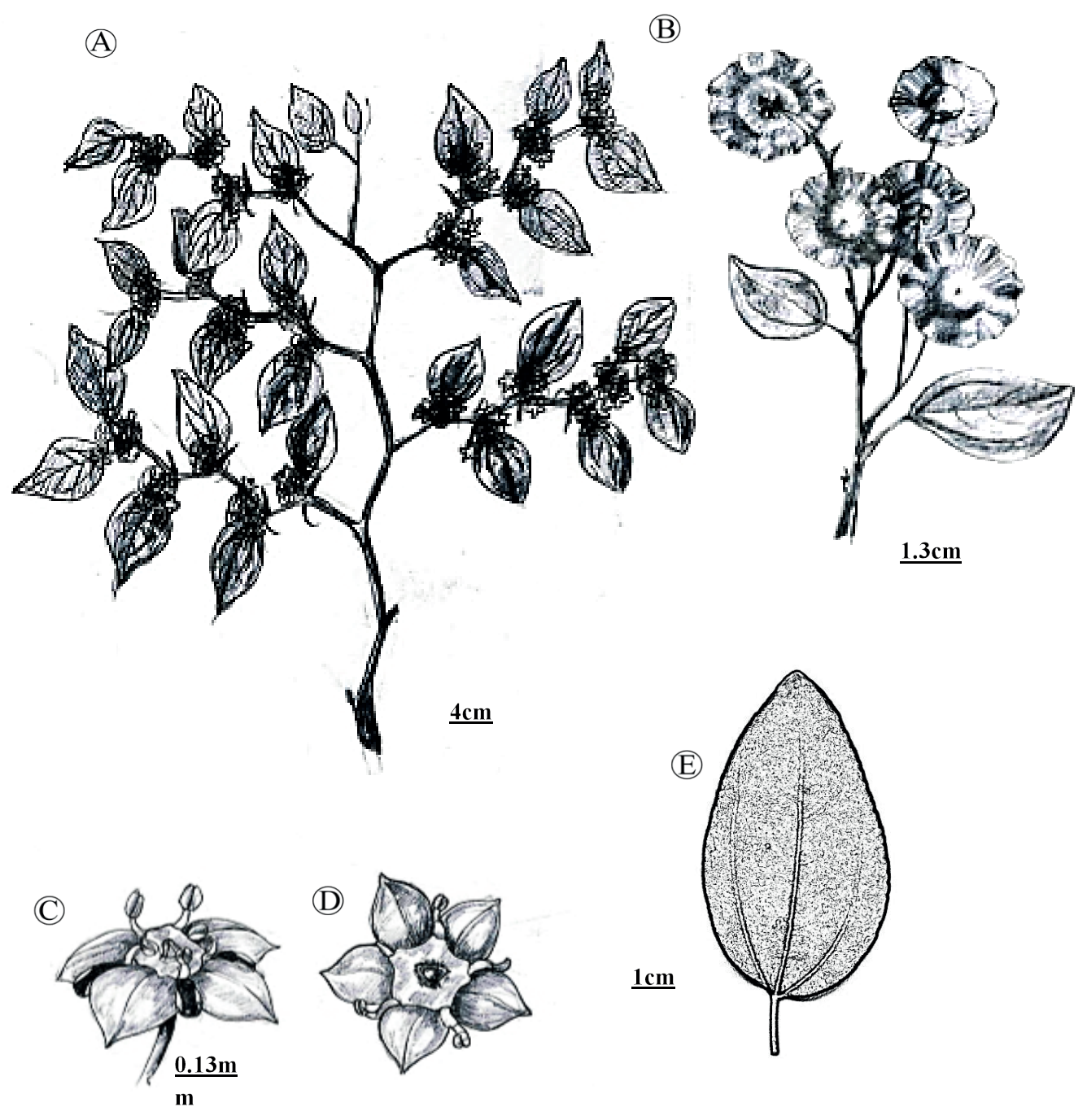

Figure 1. Paliurus spina-christi var. spina-christi: (A) Flowering twig, (B) Fruiting twig, (C, D) Bisexual flower, (E) Leaf. 


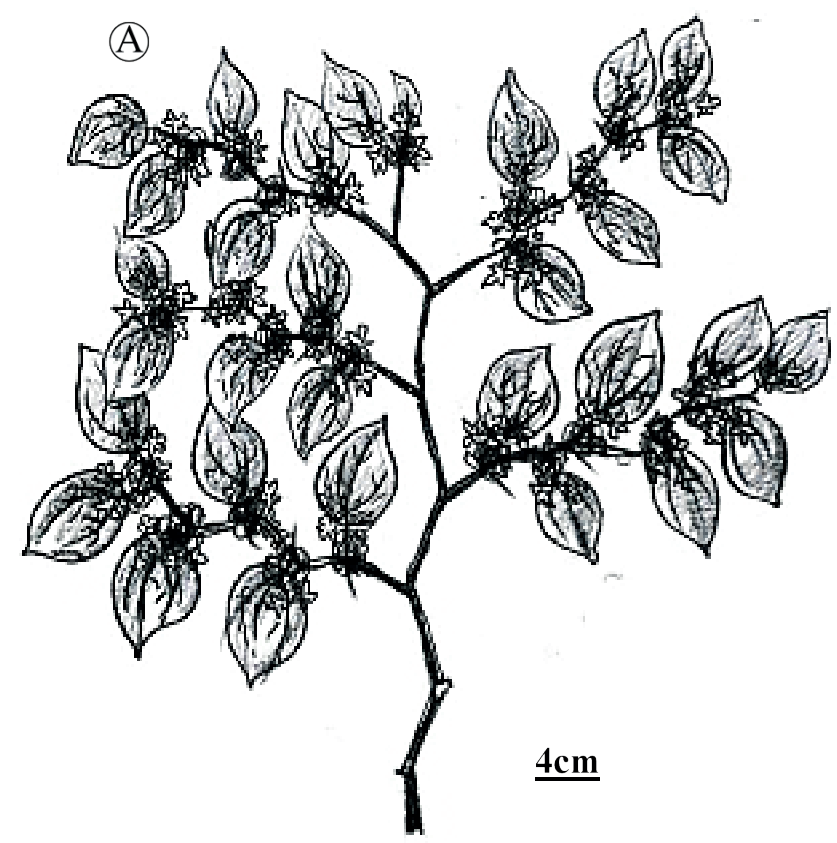

(B)

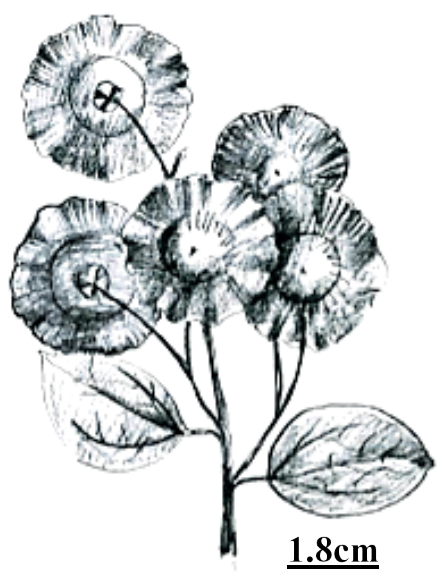

(C)

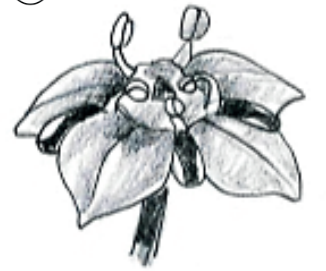

(D)

$\underline{0.15 \mathrm{~mm}}$

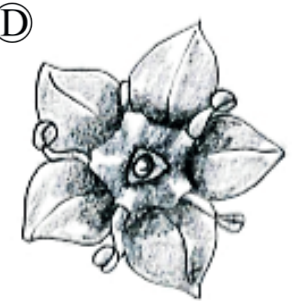

$\underline{0.2 \mathrm{~mm}}$

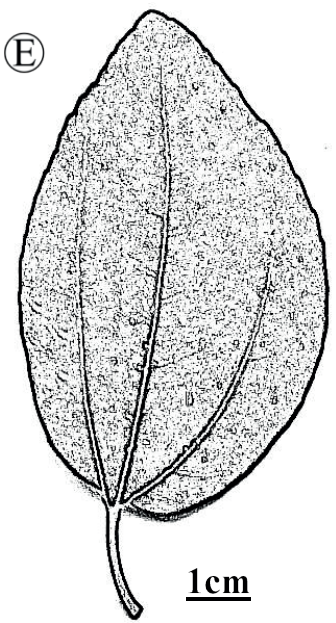

D.M.SH

Figure 2. Paliurus spina-christi var. macrocarpa: (A) Flowering twig, (B) Fruiting twig, (C, D) Bisexual flower, (E) Leaf.

\section{Anatomical characteristics}

\section{Paliurus spina-christi:}

Epidermis consists of one layer of highly variable large cells, polygonal or circular in shape with thick outer wall and thick cuticle on both abaxial and adaxial surfaces. Stomata as seen in cross section are in the same level of the epidermis or slightly sunken. Upper epidermal layer is always thicker than the lower epidermal layer for the same blade. Leaves are isobilateral or unifacial (having the same structure on both sides of the leaf). Isobilateral mesophyll in- cludes 2 layers of long palisade cells adaxially and 2-3 layers of short cells on abaxial surface. Many vascular bundles are seen equally spaced in the mesophyll tissue (Figures 3).

Midrib is little raised from the adaxial side, semicircle in the abaxial side. The vascular bundle is surrounded by a distinct parenchyma bundle sheath (border parenchyma). Two distinct thick patches of collenchyma just beneath the epidermis $(26.53-43.64 \mu \mathrm{m})$, one is at the adaxial and the other at the abaxial face leaving the two sides of the blade without the collen- 
chyma tissue. Vascular bundles are collateral cupped by the sclerenchyma and arranged in u-shape with the xylem facing the adaxial side and the phloem the abaxial side (Figure 4).

Secretory canals are common feature in the parenchymatous tissue of midribs (Figures 3, 4, 5), main leaf vein and petioles of this species showing great fluctuation in number and size, thus providing insignificant taxonomic value. For Liu et al., ${ }^{(13)}$, secretory structures in plants decrease in density with development and growth of stems and leaves.

Petiole epidermis also includes one layer of cells covered by cuticle. Outline at the midpoint is semispherical in shape convexes in abaxial side, flat or slightly concaves in adaxial side, becomes more or less elliptic at places nearer to leaf base (Figure 5). Cortex includes layers of sub epidermal collenchy$\mathrm{ma}(61.24-101.22 \mu \mathrm{m})$ followed by parenchyma layer tissue of variable width $(95.78-158.48 \mu \mathrm{m})$ (Figure 2). Secretory canals are distinct and distributed in the cortical parenchyma of the petiole. The anatomical characteristics of petiole in this species go along with their midrib and the main veins characteristics. Like midrib the vascular bundles are also u-shaped with the xylem towards adaxial and the phloem towards the abaxial face and the latter is strengthened by a well-developed sclerenchyma tissue in the same direction.

Druses are the only crystals found present in the mesophyll of P. spina-christi leaves.

Paliurus spina-christi var. spina-christi and P. spina-christi var. macrocarpa

Leaf anatomical features show no considerable differences between the two varieties of P. spina-christi. Data shown in table (2) reveals high overlapping in measured quantitative characters, no spacial distance occurs. Therefore characters are considered merely variation within the species of no taxonomic importance. The presence of simple non glandular hairs concentrated on the adaxial side of the P. spina-cristi var. spina-cristi petiole and the absence of these hairs from the same site of P. spina-cristi var. macrocarpa petiole may represent the only character of taxo- nomic application.

\section{Key to the varieties based on the petiole indu- mentum:}

P. spina-christi var. spina-christi: Simple non glandular hairs present on the adaxial side of the petiole.

P. spina-christi var. macrocarpa: Simple non glandular hairs not present on the adaxial side of the petiole.

\section{Cuticular structure}

\section{Characteristics of the two varieties}

Differences between var. spina-christi and var. macrocarpa in shape and anticlinal walls of normal epidermal cells are not distinguishable. Data displayed in table (3) shows no significant differences in cell sizes between the two varieties in both the adaxial and abaxial faces. Normal epidermal cells are significantly higher in density at the abaxial side than cells at the adaxial side, but these differences between the two varieties are insignificant because of the high data overlapping and the lake of spatial distance.

As a mean value, stomata of var. macrocarpa are considerably larger in size than stomata of var. spina-christi (table 4), but no differences are evident in stomata shape and subsidiary cells arrangement at both the abaxial and adaxial sides. Stomatal density, especially at the adaxial face may provide an important diagnostic character for separating var. spina-christi from var. macrocarpa. Number of stomata per $\mathrm{mm}^{2}$ is much higher in leaves of var. macrocarpa than in var. spina-christi.

\section{Key to the varieties based on stomatal density and size:}

P. spina-christi var. spina-christi: Stomatal density of the adaxial leaf side up to 19 stomata per $\mathrm{mm}^{2}$, adaxial and abaxial stomatal size 9.91-24.20 x 8.20-25.79 $\mu \mathrm{m}$ are smaller.

P. spina-christi var. macrocarpa: Stomatal density of the adaxial leaf side up to 38 stomata per $\mathrm{mm}^{2}$, adaxial and abaxial stomatal size 13.19-34.45 x $9.54-31.09$ $\mu \mathrm{m}$ are larger. 
Table 2. Quantitative Characters of Cells and Tissues in Cross Section of Leaf Blade, Mid-rib and Leaf Petiole of Paliurus spina-christi $(\mu \mathrm{m})$.

\begin{tabular}{|c|c|c|c|}
\hline \multicolumn{2}{|c|}{ Character } & $\begin{array}{l}\text { Paliurus spina-christi } \\
\text { var. spina-christi }\end{array}$ & $\begin{array}{c}\text { Paliurus spina-christi } \\
\text { var. macrocarpa }\end{array}$ \\
\hline \multirow{3}{*}{ Leaf thickness } & Mean & 162.78 & 163.25 \\
\hline & Range & $153.17-175.18$ & $143.11-188.87$ \\
\hline & STD & 6.80 & 14.58 \\
\hline \multirow{3}{*}{$\begin{array}{l}\text { Upper cuticle } \\
\text { thickness }\end{array}$} & Mean & 2.44 & 2.86 \\
\hline & Range & $1.98-3.02$ & $1.55-3.96$ \\
\hline & STD & 0.333 & 0.561 \\
\hline \multirow{3}{*}{$\begin{array}{l}\text { Lower cuticle } \\
\text { thickness }\end{array}$} & Mean & 1.71 & 2.01 \\
\hline & Range & $1.15-2.41$ & $1.06-2.78$ \\
\hline & STD & 0.376 & 0.491 \\
\hline \multirow{3}{*}{$\begin{array}{l}\text { Upper epidermis } \\
\text { thickness }\end{array}$} & Mean & 29.86 & 26.84 \\
\hline & Range & $25.86-33.50$ & $25.40-28.14$ \\
\hline & STD & 2.61 & 1.02 \\
\hline \multirow{3}{*}{$\begin{array}{l}\text { Lower epidermis } \\
\text { thickness }\end{array}$} & Mean & 15.72 & 15.21 \\
\hline & Range & $14.31-17.66$ & $12.03-17.55$ \\
\hline & STD & 0.914 & 1.80 \\
\hline \multirow{3}{*}{$\begin{array}{l}\text { Palisade parenchyma height, } \\
\text { first layer }\end{array}$} & Mean & 28.40 & 29.96 \\
\hline & Range & $23.61-37.80$ & $21.46-37.21$ \\
\hline & STD & 3.37 & 4.50 \\
\hline \multirow{3}{*}{$\begin{array}{l}\text { Palisade parenchyma, height } \\
\text { second layer }\end{array}$} & Mean & 23.27 & 25.67 \\
\hline & Range & $18.38-29.02$ & $19.73-30.51$ \\
\hline & STD & 2.54 & 3.38 \\
\hline \multirow{3}{*}{$\begin{array}{l}\text { Palisade parenchyma, height } \\
\text { last layer }\end{array}$} & Mean & 15.44 & 17.04 \\
\hline & Range & $11.35-20.06$ & $14.64-21.25$ \\
\hline & STD & 2.08 & 1.96 \\
\hline \multirow{3}{*}{$\begin{array}{l}\text { Palisade parenchyma one } \\
\text { cell width }\end{array}$} & Mean & 5.15 & 5.10 \\
\hline & Range & $3.79-6.34$ & $3.03-7.94$ \\
\hline & STD & 0.665 & 0.924 \\
\hline \multicolumn{4}{|c|}{ Mid-rib } \\
\hline \multirow{3}{*}{ Epidermis thickness } & Mean & 7.74 & 6.37 \\
\hline & Range & $6.72-8.44$ & $5.60-7.12$ \\
\hline & STD & 0.491 & 0.412 \\
\hline \multirow{3}{*}{ Cortex thickness } & Mean & 125.83 & 134.85 \\
\hline & Range & $96.41-158.49$ & $102.30-166.92$ \\
\hline & STD & 20.49 & 20.18 \\
\hline \multirow{3}{*}{ Collenchyma thickness } & Mean & 34.85 & 37.15 \\
\hline & Range & $26.53-43.64$ & $31.37-42.49$ \\
\hline & STD & 5.83 & 3.64 \\
\hline \multirow{2}{*}{ Parenchyma Thickness } & Mean & 81.63 & 86.75 \\
\hline & Range & $62.41-105.97$ & $57.12-115.73$ \\
\hline
\end{tabular}


Continue Table 2. Quantitative Characters of Cells and Tissues in Cross Section of Leaf Blade, Mid-rib and Leaf Petiole of Paliurus spina-christi $(\mu \mathrm{m})$.

\begin{tabular}{|c|c|c|c|}
\hline Character & & $\begin{array}{l}\text { Paliurus spina-christi } \\
\text { var. spina-christi }\end{array}$ & $\begin{array}{l}\text { Paliurus spina-christi } \\
\text { var. macrocarpa }\end{array}$ \\
\hline \multirow{3}{*}{ Fiber layer thickness } & Mean & 37.09 & 37.55 \\
\hline & Range & $30.65-43.32$ & $32.36-41.13$ \\
\hline & STD & 3.91 & 2.80 \\
\hline \multirow{3}{*}{$\begin{array}{l}\text { Sclerenchyma } \\
\text { Thickness }\end{array}$} & Mean & 68.16 & 70.25 \\
\hline & Range & $61.58-74.46$ & $59.71-78.91$ \\
\hline & STD & 4.44 & 5.90 \\
\hline \multirow{3}{*}{$\begin{array}{l}\text { vascular tissue } \\
\text { thickness }\end{array}$} & Mean & 107.63 & 125.29 \\
\hline & Range & $84.23-126.49$ & $108.47-156.66$ \\
\hline & STD & 14.93 & 14.12 \\
\hline \multirow{3}{*}{ Pith thickness } & Mean & 33.36 & 44.65 \\
\hline & Range & $25.32-40.79$ & $24.19-62.98$ \\
\hline & STD & 5.21 & 10.64 \\
\hline \multicolumn{4}{|c|}{ Petiole } \\
\hline \multirow{3}{*}{$\begin{array}{l}\text { Epidermis } \\
\text { Thickness }\end{array}$} & Mean & 8.81 & 7.97 \\
\hline & Range & $4.83-11.42$ & $6.07-10.95$ \\
\hline & STD & 1.51 & 1.11 \\
\hline \multirow{3}{*}{ Cortex thickness } & Mean & 186.17 & 228.86 \\
\hline & Range & $162.16-225.63$ & $208.17-279.12$ \\
\hline & STD & 17.86 & 21.82 \\
\hline \multirow{3}{*}{$\begin{array}{l}\text { Collenchyma } \\
\text { thickness }\end{array}$} & Mean & 68.55 & 77.81 \\
\hline & Range & $61.24-76.93$ & $71.03-87.39$ \\
\hline & STD & 4.58 & 5.70 \\
\hline \multirow{3}{*}{$\begin{array}{l}\text { Parenchyma } \\
\text { Thickness }\end{array}$} & Mean & 108.57 & 127.75 \\
\hline & Range & $95.78-135.74$ & $112.05-158.48$ \\
\hline & STD & 12.94 & 14.08 \\
\hline \multirow{3}{*}{ Fiber layer thickness } & Mean & 47.75 & 44.26 \\
\hline & Range & $41.75-55.18$ & $38.62-53.47$ \\
\hline & STD & 4.13 & 2.89 \\
\hline \multirow{3}{*}{$\begin{array}{l}\text { Sclerenchyma } \\
\text { thickness }\end{array}$} & Mean & 60.56 & 61.28 \\
\hline & Range & $47.51-74.47$ & $50.15-77.51$ \\
\hline & STD & 8.11 & 8.12 \\
\hline \multirow{3}{*}{$\begin{array}{l}\text { Vascular tissue } \\
\text { thickness }\end{array}$} & Mean & 122.13 & 108.77 \\
\hline & Range & $101.16-139.69$ & $88.11-122.41$ \\
\hline & STD & 10.85 & 11.80 \\
\hline \multirow{3}{*}{ Pith thickness } & Mean & 105.57 & 97.61 \\
\hline & Range & $79.60-131.37$ & $90.17-102.45$ \\
\hline & STD & 18.70 & 4.71 \\
\hline
\end{tabular}


Table 3. Dimension of the Epidermal Cells $(\mu \mathrm{m})$, Stomatal density (stomata per $\mathrm{mm}^{2}$ ), and stomatal index.

\begin{tabular}{|c|c|c|c|c|c|}
\hline \multicolumn{4}{|c|}{ Character } & $\begin{array}{l}\text { Paliurus spina-christi } \\
\text { var. spina-christi }\end{array}$ & $\begin{array}{c}\text { Paliurus spina-christi } \\
\text { var. macrocarpa }\end{array}$ \\
\hline \multirow{21}{*}{ Adaxial } & \multirow{9}{*}{ Epidermis cell } & \multirow{4}{*}{ Length } & Mean & 33.71 & 29.43 \\
\hline & & & Range & $21.33-51.80$ & $14.31-42.02$ \\
\hline & & & STD & 6.58 & 6.66 \\
\hline & & & Mean & 22.46 & 18.20 \\
\hline & & \multirow{3}{*}{ Width } & Range & $12.58-33.13$ & $12.40-24.19$ \\
\hline & & & STD & 4.24 & 2.78 \\
\hline & & & Mean & 1843.16 & 1854.08 \\
\hline & & \multirow{2}{*}{$\begin{array}{l}\text { Density/ } \\
\mathrm{mm}^{2}\end{array}$} & Range & $1684-1981$ & $1696-1984$ \\
\hline & & & STD & 76.54 & 83.10 \\
\hline & \multirow{12}{*}{ Stomata } & \multirow{4}{*}{ Length } & Mean & 21.10 & 25.92 \\
\hline & & & Range & $16.68-24.20$ & $21.49-34.45$ \\
\hline & & & STD & 2.61 & 3.43 \\
\hline & & & Mean & 14.02 & 18.45 \\
\hline & & \multirow{3}{*}{ Width } & Range & $9.91-17.71$ & $13.19-25.41$ \\
\hline & & & STD & 2.31 & 2.71 \\
\hline & & & Mean & 9.28 & 24.96 \\
\hline & & \multirow{3}{*}{$\begin{array}{c}\text { Density/ } \\
\mathrm{mm}^{2}\end{array}$} & Range & $4-19$ & $17-38$ \\
\hline & & & STD & 4.08 & 6.49 \\
\hline & & & Mean & 0.501 & 1.33 \\
\hline & & \multirow{2}{*}{ Index } & Range & $0.207-1.06$ & $0.849-2.16$ \\
\hline & & & STD & 0.222 & 0.359 \\
\hline \multirow{21}{*}{ Abaxial } & \multirow{9}{*}{ Epidermis cell } & \multirow{4}{*}{ Length } & Mean & 24.26 & 26.42 \\
\hline & & & Range & $17.25-32.07$ & $16.48-35.14$ \\
\hline & & & STD & 4.02 & 4.71 \\
\hline & & & Mean & 16.10 & 15.89 \\
\hline & & \multirow{3}{*}{ Width } & Range & $9.24-24.88$ & $11.22-21.82$ \\
\hline & & & STD & 2.61 & 2.82 \\
\hline & & & Mean & 2556.56 & 2464.44 \\
\hline & & \multirow{2}{*}{$\begin{array}{c}\text { Density/ } \\
\mathrm{mm}^{2}\end{array}$} & Range & $2375-2756$ & $2286-2734$ \\
\hline & & & STD & 100.62 & 139.52 \\
\hline & \multirow{12}{*}{ Stomata } & \multirow{4}{*}{ Length } & Mean & 19.38 & 24.87 \\
\hline & & & Range & $11.32-25.79$ & $15.36-31.09$ \\
\hline & & & STD & 3.15 & 3.48 \\
\hline & & & Mean & 12.20 & 12.81 \\
\hline & & \multirow{3}{*}{ Width } & Range & $8.20-17.48$ & $9.54-18.81$ \\
\hline & & & STD & 2.33 & 1.94 \\
\hline & & & Mean & 296.56 & 340.88 \\
\hline & & \multirow{3}{*}{$\begin{array}{c}\text { Density/ } \\
\mathrm{mm}^{2}\end{array}$} & Range & $241-375$ & $283-394$ \\
\hline & & & STD & 38.71 & 31.37 \\
\hline & & & Mean & 10.38 & 12.14 \\
\hline & & \multirow{2}{*}{ Index } & Range & $8.90-13.43$ & $10.71-13.44$ \\
\hline & & & STD & 1.25 & 0.779 \\
\hline
\end{tabular}




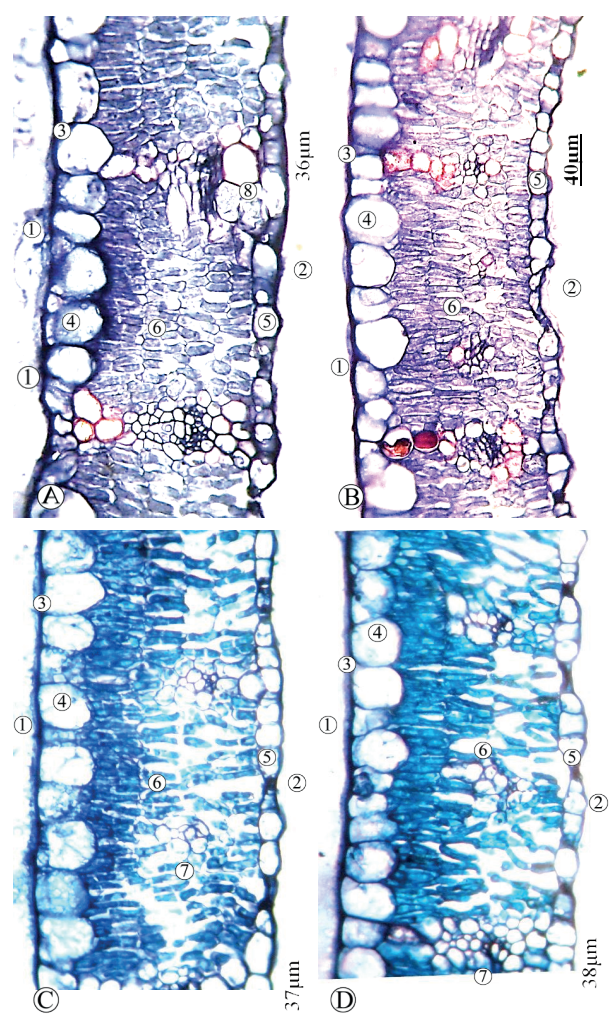

Figure 3. Leaf blade cross section. (A-B) Paliurus spina-christi var. spina-christi, (C-D) Paliurus spina-christi var. macrocarpa: 1. Adaxial face, 2. Abaxial face, 3. Cuticle layer, 4. Upper epidermal layer, 5. Lower epidermal layer, 6. Palisade parenchyma, 7. Veinlet vascular bundle, 8. Druses crystal.

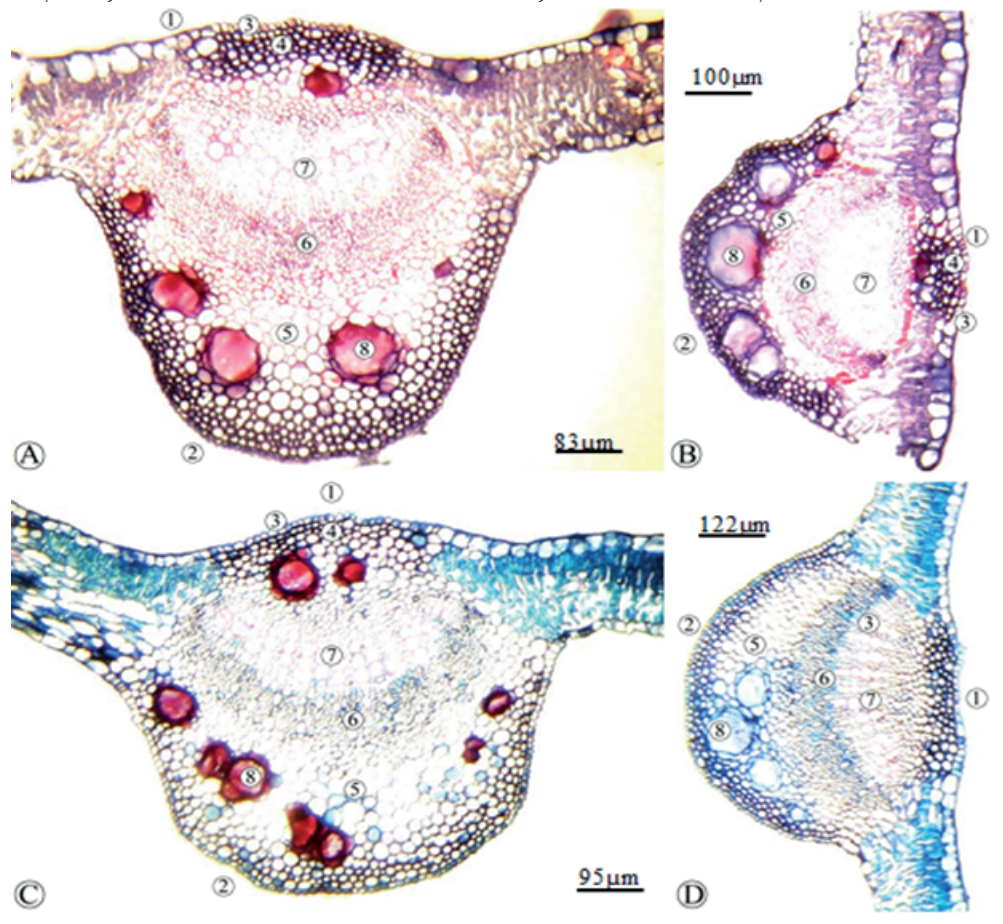

Figure 4. (A-B) Paliurus spina-christi var. spina-christi, (A) Midrib cross section (B) Main vein cross section, (C-D) Paliurus spina- 1s. 

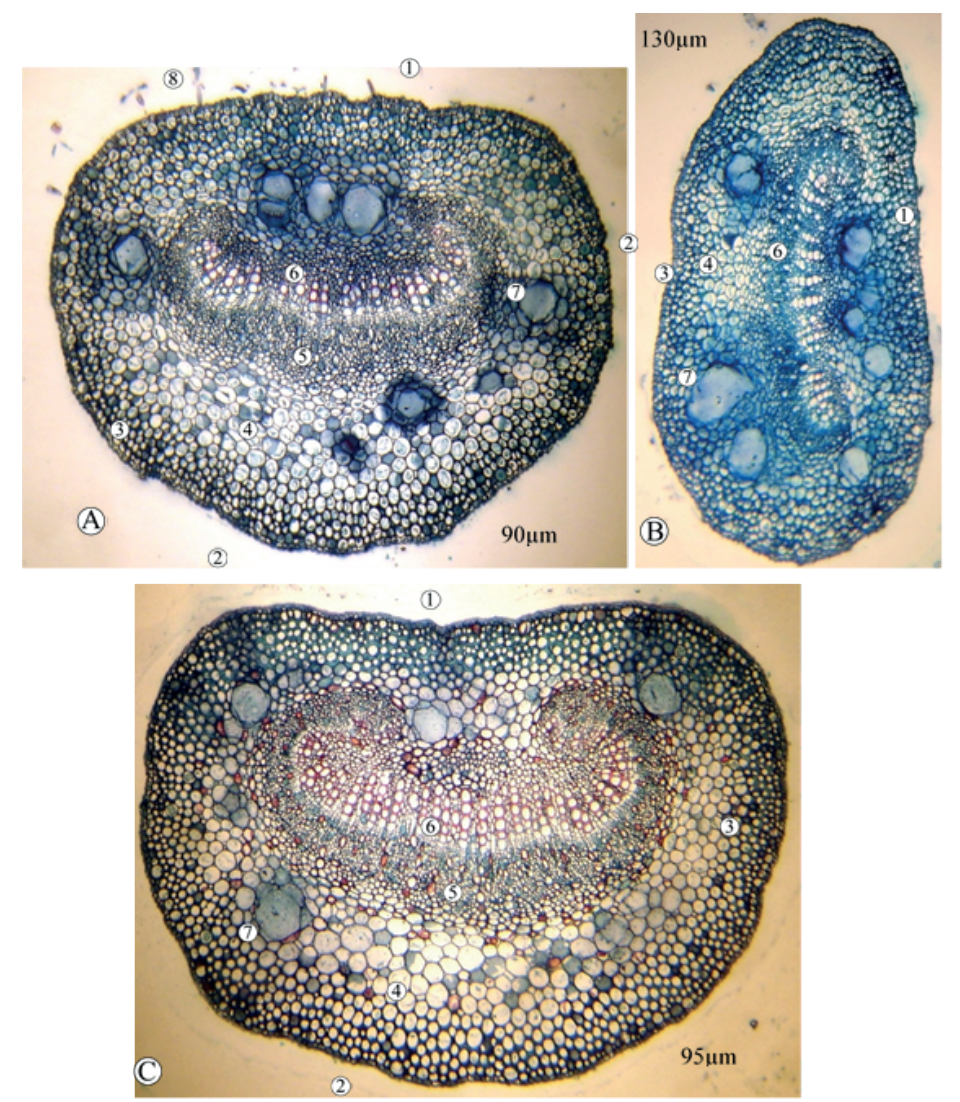

Figure 5. (A-B) Paliurus spina-christi var. spina-christi, (A) Petiole cross section (B) Petiole cross section near leaf base, (C) Leaf petiole cross section of Paliurus spina-christi var. macrocarpa: 1. Adaxial face, 2. Abaxial face, 3. Collenchyma, 4. Parrenchyma, 5. Sclerenchyma, 6. Vascular bundle, 7. Secretory canals, 8. Unicellular hair.
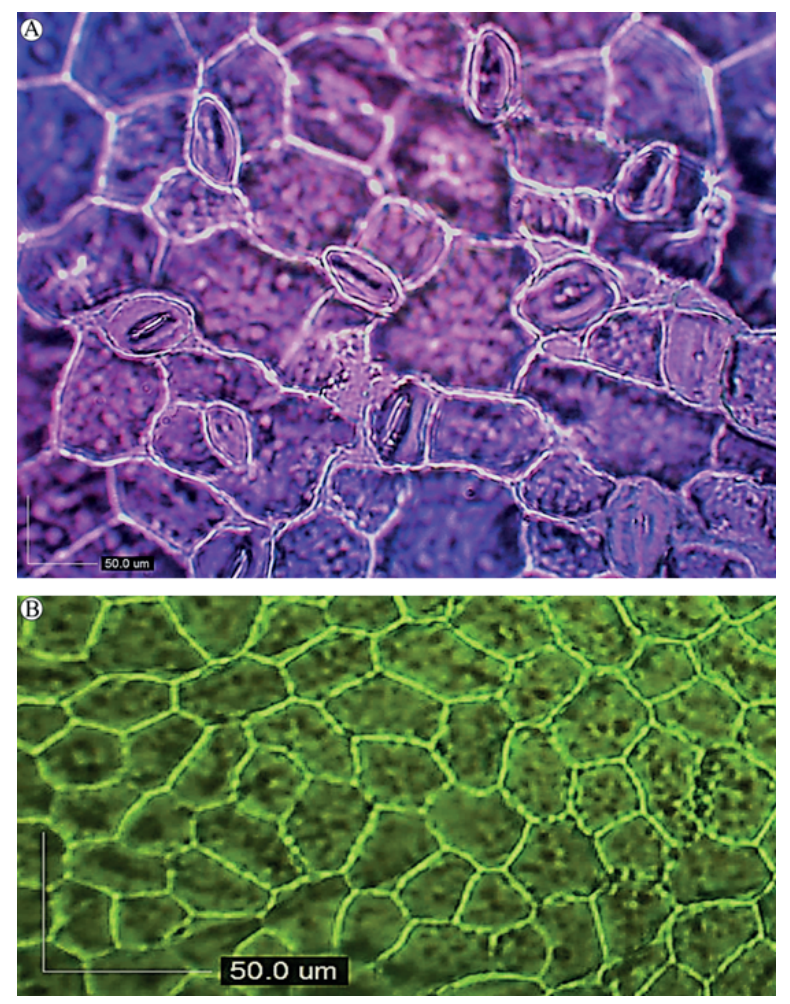

Figure 6. Leaf cuticular structure of Paliurus Spina-christivar. Spina-christi: (A) Abaxial epidermis, (B) Adaxial epidermis. 


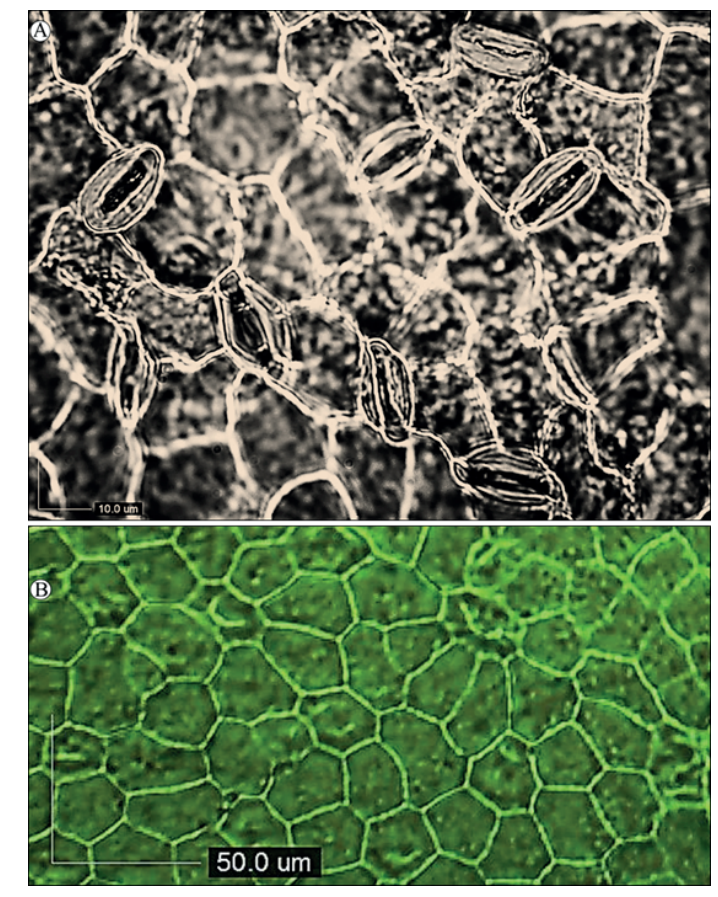

Figure 7. Leaf cuticular structure of Paliurus Spina-christi var. macrocarpa: (C) Abaxial epidermis, (D) Adaxial epidermis.

\section{REFERENCES}

1. Townsend C C, and Guest E (Eds.). Flora of Iraq. Ministry of Agriculture and Agrarian Reform, Baghdad-Iraq. 1980, Vol.4.

2. Xiangchuan L I, Wang H., Leng Q., Xiao L., Guo J., Wenlong H E. Paliurus (Paliureae, Rhamnaceae) from, the Miocene of East China and its Macrofossil-based Phylogenetic and Phytogeographical History. Acta Geologica Sinica (English Edition) 2014; 88, (5): 1364-1377.

https://doi.org/10.1111/1755-6724.12304

3. Chen Yi-ling and Chou Pan-kai. Rhamnaceae. In: Chen Yi-ling, ed., Fl. Reipubl. Popularis Sin. 1982; 48(1): i-vi, 1-169.

4. Basinger J, and Dilcher D. Ancient bisexual flowers. Science 1984; 224: 511-513.

https://doi.org/10.1126/science.224.4648.511

5. Manchester S R. (1999). Biogeographical relationships of North American Tertiary floras. Ann Mo Bot Gard 1999; 86:472-522. https://www.jstor. org/stable/2666183.

https://doi.org/10.2307/2666183

6. Merev N, Gerçek Z, and Serdar B. Wood anatomy of some Turkish plants with special reference to perforated ray cells. Turkish Journal of Botany 2005; 29: 269-281.
7. Zarinkamar F. Comparative foliar anatomy of five xerophyte species from Iran. Iranian Journal of Botany 1993; 6: 153-168.

8. Dinarvand M, and Zarinkamar F. Anatomy-taxonomy of the genus Ziziphus in Iran. Iranian Journal of Botany 2006; 12: 36-41.

9. Raeder-Roitzsch J E. Forest trees in Iraq. Bab. Fac. of Agriculture, University of Mosul, Iraq, 1969.

10. Holmgren K P, and Keuken W. Intermountain Flora: Vascular plants of the intermountain west, U.S.A. 1989; 3B: 1-279. New York Botanical Garden, Bronx, New York.

11. Fathoulaah Ch N. Biological and Anatomical study of different Cuscta species. Msc. Thesis, Salahaddin Univ., Coll. Of Sci.: P: 19. featuers. Ann. Misouri Bot. Garden 2005; 73: 228-275.

12. Saeed, J. F. Systematic study of the genus Campanula L. (Campanulaceae) in Iraq Ph.D. Thesis, Educ. Coll. Salahaddin Univ. Erbil. 2003, (In Arabic).

13. Liu Z, Carpenter S B, Bourgeois W J, Yu Y, Constantin R J, Falcon M J, and Adams J C. Variation in the secondary metabolite camptothecin in relation to tissue age and season in Camptotheca acuminata (Nyssaceae). Tree Physiol, 1998; 18: 265-270.

https://doi.org/10.1093/treephys/18.4.265 